
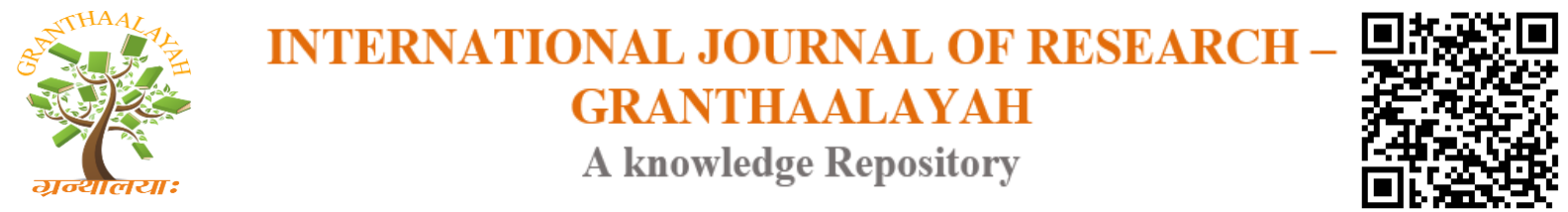

Management

\title{
GREEN BANKING IN INDIA: PROBLEMS AND PROSPECTS
}

\author{
Dr. Bibhu Prasad Sahoo ${ }^{1}$, Mr. Amandeep Singh ${ }^{2}$, Mr. Neeraj Jain ${ }^{3}$ \\ 1,2,3 Assistant Professor, SGTB Khalsa College, INDIA
}

DOI: https://doi.org/10.29121/granthaalayah.v4.i8.2016.2566

\section{ABSTRACT}

Green banking is different from traditional banking, as green banking focus on promoting environment friendly banking. Green banking is also known as ethical banking. This paper attempts to analyze the adoption of green banking products among customers with different age groups. ANOVA and post hoc tests are applied for analyzing the objectives. This paper finding explains that there is significant difference in the usage of green banking products across various age groups individuals, as young generation is more inclined towards green banking products than middle age and senior age groups. Therefore, more awareness is need to be created among the middle and senior age groups individuals.

Keywords:

Green banking, traditional banking, environment friendly banking, ethical banking.

Cite This Article: Dr. Bibhu Prasad Sahoo, Mr. Amandeep Singh, and Mr. Neeraj Jain, "GREEN BANKING IN INDIA: PROBLEMS AND PROSPECTS" International Journal of Research - Granthaalayah, Vol. 4, No. 8 (2016): 92-99.

\section{INTRODUCTION}

Today, the way we are recklessly consuming resources on earth, the question arises what we will leave for future generation. The concept of sustainable development that is taking care of the need of present generation without compromising the needs of future generation, has given rise to green marketing and then green banking. Green banking is different from conventional banking as convention is based on the principal of security and profitability and morality has a very little role. Green banking is a new concept that considers environmental and socially responsible investing. Green banking is defined as promoting environmental-friendly practices and reducing the carbon footprint from banking activities. In simple words, green banking is a banking that benefits the environment. The green banking is also known as ethical banking. The bank can minimal the use of paperwork by promoting paperless banking through online banking. To initiate sustainable development, there is a need to promote green banking practices so that we can tackle the problems like global warming, natural calamities, and disaster. Bank is a financial institution that deals with masses and banks by adopting green activities can influence the attitude of the customers towards the environment. The concept and practice of green 
banking is new to India, but not in developed nations like the USA. There is a need to focus on sustainable banking to protect the environment from disaster. The performance of bank's clients impact the performance of banks so there is a need for appropriate environmental and social due diligence to reduce the chance of non-performing assets, as legal environmental compliance failure can halt the client's project and result in NPA to the bank. Bank should take into consideration the ecological aspect in lending apart from security and profitability. Various international protocols such as UNEPFI, Equator Principles, and LEED certificates have been issued in order to facilitate green banking, but Indian banks are still lagging behind. Various banks in India have formulated strategies and initiated green banking practices to support environment-friendly banking and reduce the carbon footprints of bank and customers. The banks in India also started green banking practices such as online banking, mobile banking, Green channel counters, e-statement, green loans, solar ATMs, etc. The issues of global warming should not be only restricted to a debate but has to be dealt with going green. Thus, green banking is one of the ways of going green. There is a need to involve key stakeholders and creating awareness about environment-friendly banking.

\section{REVIEW OF LITERATURE}

A general scanning of literature available in India from different published sources indicates that very few detailed studies have been conducted in India in the field of Banking, particularly in the field of Green Banking. However, many studies have been conducted abroad, particularly in the western developed countries. But these are not very relevant in Indian context. This section reviews empirical literature on Green Banking conducted in country as well as abroad in chronological order.

Jeucken and Bouma (1999) in their study identified four stages or attitudes of banking toward sustainability. The first stage is defensive banking, in which bank is non-active and tries to delay or oppose the new legislation as it may damage the interest of banks directly or indirectly. The Second stage is preventive banking in which bank has to comply with legislation to avoid any constraint on its activities. The third stage is offensive banking in which banks are concerned about internal as well as external activities. The final stage is sustainable banking, which is, a win-win solution. Banks under this stage looks for highest sustainable rate of return not for highest financial rate of return. Getzner and Kra"uter (2004) in their research paper tested the respondents' willingness to invest in green shares. Authors found education, income, environmental awareness and the expected profit are the main explanatory variables.

The study by Bhardwaj and Malhotra (2014) linked the performance of bank with the green banking adoption. They found a positive relationship between adoption of green banking and bank profitability. On the other hand, similar study by Rajput, Arora, and Khanna (2014) found no relationship between green banking initiatives and bank's profitability. Sudhalakshmi and Chinnadorai (2014) studied the green banking adoption status of Indian banks. Their study showed that not many initiatives have been taken by banks in India as far as green banking is concerned. They concluded that banks have to play a proactive role in order to take environmental and ecological aspect as a part of their lending process, which would force industries to go for mandated investment for environmental management. Similarly, Ahmed (2012) discussed the contemporary green banking initiatives taken globally and more specifically 
in Bangladesh. He gave policy recommendation which included giving rewards to the banks for positive green banking initiatives by developing green index rating and building awareness amongst the stakeholder such as Competitors, Corporate Consumer, and non-Corporate Consumer, employee, employee union and Government Regulatory Organization.

At policy level, Choudhury et al. (2014) advocated for the necessity of stakeholder's influences in green banking practice and recommends some indication for Government, the whole banking sector and for the business community. Bahl (2012) suggested RBI and Indian government should play a proactive and formulate green banking policy, guidelines \& financial incentives for effective green banking.

Nath, Nayak, and Goel(2014) conducted a study on green banking practices and recommended for change in routine operations of banks by adoption of paperless banking, online banking, and mobile banking, and mass transportation system, green cards made up of recycled plastic. They carried out SWOC analysis wherein, they explained time and cost saving as the major strength, lack of infrastructure, computer illiteracy are the major weakness, opportunities that are available is people are becoming tech-savvy and environmentally conscious, but the major challenge is internet connectivity and moreover no banking practices are not fully secured.(world finance conference). Kalloch and Bachman (2011) highlighted the online and small community banks are seen as greener than large banks. One big criticism of large banks is that they finance environmentally detrimental endeavors.

Papastergiou and Blanas (2011) conducted study on "Sustainable Green Banking: The Case of Greece and approached the area in an integrated and innovative way. According to their finding, they identified 50\% banks were in defensive phase, $40 \%$ in preventive, and $10 \%$ in offensive stage. KO et al. (2014) in their research paper found that there is a significant positive relationship between green concern and internet use. Their study shows that 'bank's customers are more concerned about environmental problems and they are willing to go green, following other people who are making green efforts". Green concern as a construct of social influence dimension significantly influence use of internet banking. The study also indicated word of mouth communication from friends and family significantly influences the internet usage. Similarly, Singh and Singh (2012) in their paper expressed society's growing concern about the natural environment, the business organization are also modifying their working in order to increase greenery.

Rajput, Khanna and Kaur (2014) in their study endeavors made by SBI, the market leader in Educational Loans, Auto Loans, and the no.1 home loan, on the road of green banking and sustainable development. The Bank has also been an active participant in wildlife conservation projects like 'Save the Tiger'. State Bank of India has become a signatory investor to the Carbon Disclosure Project (CDP) to disclose its carbon footprints. Ahmed, Zayed and Harun (2014) in their study applied factor analysis and finding revealed that six factors namely six factors namely economic factor, policy guideline, loan demand, stakeholder pressure, environmental interest, and legal factor were the major factors behind the green banking adoption in Bangladesh. Verma (2012) in his study explained the evolution of green banking in India, and highlight that now banks are incorporating green banking practices in CSR as a main activity. However, his study 
concluded that only few banks in India adopted green banking and there is lack of awareness among the bank staff and customers.

Conclusions: The research in the area of green banking primarily focused on adoption of green banking product and its performance with profitability. Some studies have gone beyond traditional inputs and suggested for policy decisions for Government and Central Bank. But very few studies has been conducted that have linked the adoption of green banking product with individual factors like age, occupation, gender or financial literacy etc. Taking in to consideration the limitation of the above studies on Green Banking so far, the need for a systematic study on Adoption of Green Banking in India is felt by us.

\section{OBJECTIVES OF THE STUDY}

The adoption of green banking has many dynamic. It is always important for decisions makers to know how the usage of green banking product is different among various age groups, gender, and occupants. Geographical location, accessibility of green banking products, and financial literacy also play an important role in the adoption of green banking products. It enables the decisions makers to determine which group need to be more focused and targeted because green banking not only provides convenient to the customer but also help the banks to reduce their cost. However, due to time and money constraint, the present study only focus on examining the relationship between age groups and adoption of green banking product.

\section{RESEARCH HYPOTHESES}

On the basis of above-mentioned objectives, the present study aims to test the following hypothesis:

$\mathrm{H}_{0}$ : The mean usage of green banking products (adoption) is independent of age.

$\mathrm{H}_{1}$ : The mean usage of green banking products is not independent of age.

\section{RESEARCH METHODOLOGY}

To test the relationship between adoption of green banking products and age of individuals, the following methodology has been applied:

\subsection{DATA COLLECTION AND SAMPLE SIZE}

The data for adoption of green banking product and age pattern have been collected through structured questionnaire. The questionnaire includes thirteen question on the usage of green banking products, namely Solar ATMs, Mobile banking, Green channel counters, Online banking, Green mortgages, Green remit cards, Green credit card, Online savings account, Green certificate of deposits, Green checking account, E-Investment services, Bonds and mutual fund for environmental friendly project, and Recyclable debit \& credit cards. The individual usage score for each green banking product has been calculated on 5 likert point scale, where, likert scale measure frequency of usage of green banking products. The score of one represents, the product has never been used by respondent, whereas, the score of five means product is being 
used very often. The 112 questionnaires have been distributed personally and online through Google forms to the sample respondent. Samples are drawn from various regions of Delhi-NCR.

\subsection{SAMPLING TECHNIQUES}

To select the sample, the following sample techniques have been used:

1) Judgmental Sampling: Judgmental sampling is a non-probability sampling technique where the researcher selects units to be sampled based on their knowledge and professional judgment.

2) Snowball Sampling: A non-probabilistic sampling technique in which an initial group of respondents is selected randomly. Subsequent respondents will be selected based on the referrals or information. This technique also has been used in the present study by asking for referrals from the respondent.

3) Convenience Sampling: Convenience sampling is a non-probability sampling technique where subjects are selected because of their convenient accessibility and proximity to the researcher.

\subsection{STATISTICAL TECHNIQUES}

The Analysis of Variance, popularly known as the ANOVA, is used in cases where there are more than two groups. In order to test the null hypothesis, Analysis of Variance and Post hoc Multiple Comparisons test has been applied. To test the equality of variance among various age groups, Levene test has been applied.

\section{DATA ANALYSIS AND RESULTS}

The descriptive statistics of mean usage of green banking products across various age groups have been shown in Table 1. The descriptive statistics shows that the usage of green banking product is high among individuals of age groups of 15-30, with mean score of 26.51, whereas, the usage is minimum among individuals of age above 60 with mean usage of 15 only. The standard error of the mean score for each group is between one and two, which is consistent and moderately low.

Table 1: Descriptive statistics of green banking product across various age group

\begin{tabular}{|c|c|c|c|c|c|c|c|c|}
\hline \multirow{2}{*}{$\begin{array}{l}\text { Age } \\
\text { Groups }\end{array}$} & \multirow[b]{2}{*}{$\mathrm{N}$} & \multirow[b]{2}{*}{ Mean } & \multirow{2}{*}{$\begin{array}{l}\text { Std. } \\
\text { Deviation }\end{array}$} & \multirow[b]{2}{*}{ Std. Error } & \multicolumn{2}{|c|}{$95 \%$ Confidence Interval for Mean } & \multirow[b]{2}{*}{ Minimum } & \multirow[b]{2}{*}{ Maximum } \\
\hline & & & & & Lower Bound & Upper Bound & & \\
\hline $\begin{array}{l}15-30 \\
30-45 \\
45-60 \\
60 \text { Above } \\
\text { Total }\end{array}$ & $\begin{array}{l}66 \\
27 \\
15 \\
4 \\
112\end{array}$ & $\begin{array}{l}26.5152 \\
26.0741 \\
22.9333 \\
15.0000 \\
25.5179\end{array}$ & $\begin{array}{l}9.09648 \\
7.74560 \\
7.38209 \\
2.30940 \\
8.66492\end{array}$ & $\begin{array}{l}1.11970 \\
1.49064 \\
1.90605 \\
1.15470 \\
.81876\end{array}$ & $\begin{array}{l}24.2790 \\
23.0100 \\
18.8453 \\
11.3252 \\
23.8954\end{array}$ & $\begin{array}{l}28.7513 \\
29.1381 \\
27.0214 \\
18.6748 \\
27.1403\end{array}$ & $\begin{array}{l}13.00 \\
13.00 \\
13.00 \\
13.00 \\
13.00\end{array}$ & $\begin{array}{l}49.00 \\
49.00 \\
39.00 \\
17.00 \\
49.00\end{array}$ \\
\hline
\end{tabular}

To test the hypothesis, is usage of green banking products (adoption) independent of age, ANOVA test has been conducted. The result of ANOVA test has been shown in Table 2. The $p$ value of chi-square statistics is found to be 0.039 (less than 0.05), which reject our null hypothesis that usage of green banking is independent of Age. Since, ANOVA test assume 
variance is equal across various group age group, therefore, to test the equality of variance, Leven test ${ }^{1}$ has been applied and results have been shown in Table 3.

Table 2: ANOVA results of test of equality of mean usage across various age groups

\begin{tabular}{|l|l|l|l|l|l|}
\hline & Sum of Squares & df & Mean Square & F & Sig. \\
\hline Between Groups & 616.694 & 3 & 205.565 & 2.877 & .039 \\
Within Groups & 7717.270 & 108 & 71.456 & & \\
Total & 8333.964 & 111 & & & \\
\hline
\end{tabular}

Table 3: Test of Homogeneity of Variance

\begin{tabular}{|l|l|l|l|}
\hline Levene Statistic & df1 & df2 & Sig. \\
\hline 1.838 & 3 & 108 & .145 \\
\hline
\end{tabular}

The $p$ value for Levene statistics is more than 0.05 which provide evidence of equality of variance. The limitation of ANOVA is that it does not explain which group account for significant difference in the mean. If mean usage is not equal among various groups, then ANOVA is not sufficient to identify which group causes the inequality or for which group there exist significant differences. Therefore, to identify which groups have significant difference in mean usage of green banking product, post hoc analysis has been performed and results have been shown in Table 4.

Table 4: Post hoc analysis of mean usage of green banking products across various ages.

\begin{tabular}{|c|c|c|c|c|c|c|}
\hline \multirow[b]{2}{*}{ (I) Age } & \multirow[b]{2}{*}{ (J) Age } & \multirow{2}{*}{$\begin{array}{l}\text { Mean Difference } \\
(\mathrm{I}-\mathrm{J})\end{array}$} & \multirow[b]{2}{*}{ Std. Error } & \multirow[b]{2}{*}{ Sig. } & \multicolumn{2}{|c|}{ 95\% Confidence Interval } \\
\hline & & & & & Lower Bound & Upper Bound \\
\hline \multirow[t]{3}{*}{$15-30$} & $30-45$ & .44108 & 1.93111 & .996 & -4.5981 & 5.4803 \\
\hline & $45-60$ & 3.58182 & 2.41794 & .452 & -2.7277 & 9.8914 \\
\hline & 60 Above & $11.51515^{\pi}$ & 4.35278 & .046 & .1566 & 22.8737 \\
\hline \multirow[t]{3}{*}{$30-45$} & $15-30$ & -.44108 & 1.93111 & .996 & -5.4803 & 4.5981 \\
\hline & $45-60$ & 3.14074 & 2.72218 & .657 & -3.9628 & 10.2442 \\
\hline & 60 Above & 11.07407 & 4.52886 & .075 & -.7439 & 22.8921 \\
\hline \multirow[t]{3}{*}{$45-60$} & $15-30$ & -3.58182 & 2.41794 & .452 & -9.8914 & 2.7277 \\
\hline & $30-45$ & -3.14074 & 2.72218 & .657 & -10.2442 & 3.9628 \\
\hline & 60 Above & 7.93333 & 4.75687 & .346 & -4.4796 & 20.3463 \\
\hline \multirow[t]{3}{*}{60 Above } & $15-30$ & -11.51515 & 4.35278 & .046 & -22.8737 & -.1566 \\
\hline & $30-45$ & -11.07407 & 4.52886 & .075 & -22.8921 & .7439 \\
\hline & $45-60$ & -7.93333 & 4.75687 & .346 & -20.3463 & 4.4796 \\
\hline
\end{tabular}

*. The mean difference is significant at the 0.05 level.

The post hoc analysis shows a significant difference between age group of 15-30 and 60 above, with p-value of 0.046 , which is cause for difference in mean usage of green banking products across various age groups. Our results show that the usage of green banking products is not same across various age groups. The present study finds significant difference in usage of green banking products between age group of 15-30 and 60 above.

\section{PARADIGM OF THE STUDY}

No study is immune to limitations. The present study suffers from the following limitation:

\footnotetext{
${ }^{1}$ The null hypothesis is variance of mean usage of green banking products is equal among various age group.
} 
1) The present study only tests for usage of green banking products among various age group. No separate study has been conducted to find out why adoption of green banking products is more popular for one age group than others.

2) The results in the present study are based on sample of 112 only, which is comparatively very small as compared to the overall population.

3) To select sample, the present study has used the convenient sample. So, the results may be influenced by sampling error.

\section{CONCLUSIONS}

Green banking is defined as promoting environmental-friendly practices and reducing the carbon footprint from banking activities. It involves use of online banking, mobile banking, green channel counters, e-statement, green loans, solar ATMs etc. i.e. using banking services through online activities. It is a common perception that it is more customary among youth, whereas less popular among aged people. Therefore, the present study test for usage of green banking habit among various age groups.

The present study finds that the young generation is more inclined towards green banking products then middle age and senior age groups (above 60 years). The mean score of usage of green banking products among low age group (15-30) is 26.50, whereas, it is just 15 for individuals age above 60 . Therefore, the present study finds that there is more of need to create awareness about green banking products adoption among the middle and senior age groups individuals than young age people.

\section{REFERENCES}

[1] Bahl, S. (2012). The role of green banking in sustainable growth.International Journal of Marketing, Financial Services and Management Research, 1(2), 27-35.

[2] Bailey, A. A. (2005). Consumer Awareness and Use of a Product Review Websites.Journal of Interactive Advertising, Vol. 7, No. 1, PP 78-81.

[3] Bhardwaj, B. R. \&Malhotra, A. (2014). Green Banking Strategies: Sustainability through Corporate Entrepreneurship. Greener Journal of Business \& Management studies, Vol. 4, No. 4, PP 180-191.

[4] Choudhury, T.T., et al. (2014). Influence of Stakeholders in Developing Green Banking Products in Bangladesh.Research Journal of Finance and Accounting, Vol.4, No.7, PP 77-77.

[5] Jha, N. \&Bhome, S. (2014). A Study of Green Banking Trends In India. International Monthly Referred Journal of Research In Management \& Technology, Vol. 2, PP 127142.

[6] Ko, M. et al. (2014). Customer Personality, Their Perception \& Green Concern on Internet Banking Use. Journal of Information Technology Management, Vol. 11, No. 10, PP 1-14.

[7] Kokkinaki, F. (1999).Predicting Product Purchase \& Usage: The Role of Perceived Control, Past Behaviour\& Product Involvement.Advances in consumer Research, Vol. 27, PP 577-584. 
[8] Meena, R. (2014). Green Banking: As Initiative for Sustainable Development. Global Journal of Management and Business Studies, 4(10), pp 1181-87.

[9] Nath, V., Nayak, N. \&Goel , A. (2014). Green Banking Practices - A Review.International Journal of research In Business Management, Vol.2, No. 4, PP 45 72.

[10] Sharma, N. et al. (2014). A Study on Customer's Awareness on green Banking Initiatives In Selected Public \& Private Sector Banks with Special Reference to Mumbai. IOSR Journal of Economics \& Finance, PP 28-45.

[11] Singh, K. (2011).Innovated Technology in Banking Services. Journal of Internet Banking and Commerce, 17(2), pp 1-15.

[12] Sudhalakshmi, K. and Chinnadorai, K. M. (2014).Green Banking Practices in Indian Banks. International Journal of Management and Commerce Innovations, 2(1), pp 242245.

[13] Yadav, R. and Pathak, G. S. (2014). Environmental Sustainability http://www.icicibank.com/go-green/Index.htmlthrough Green Banking: A Study on Private and Public Sector Banks in India. International Journal of Sustainable Development, 7(8), pp 47-48. 